Bowes, M.J.; Gozzard, E.; Johnson, A.C.; Scarlett, P.M.; Roberts, C.; Read, D.S.; Armstrong, L.K.; Harman, S.A.; Wickham, H.D.. 2012 Spatial and temporal changes in chlorophyll-a concentrations in the River Thames basin, UK: are phosphorus concentrations beginning to limit phytoplankton biomass? Science of the Total Environment, 426. 45-55.

10.1016/.jscitotenv.2012.02.056

Crown copyright (C) 2012 Published by Elsevier B.V

This version available http://nora.nerc.ac.uk/19374/

NERC has developed NORA to enable users to access research outputs wholly or partially funded by NERC. Copyright and other rights for material on this site are retained by the rights owners. Users should read the terms and conditions of use of this material at http://nora.nerc.ac.uk/policies.html\#access

NOTICE: this is the author's version of a work that was accepted for publication in Science of the Total Environment. Changes resulting from the publishing process, such as peer review, editing, corrections, structural formatting, and other quality control mechanisms may not be reflected in this document. Changes may have been made to this work since it was submitted for publication. A definitive version was subsequently published in Science of the Total Environment [426. 45-55 (2012)] 10.1016/i.scitotenv.2012.02.056

Contact CEH NORA team at noraceh@ceh.ac.uk

The NERC and CEH trademarks and logos ('the Trademarks') are registered trademarks of NERC in the UK and other countries, and may not be used without the prior written consent of the Trademark owner. 


\title{
Spatial and temporal changes in chlorophyll-a concentrations in the River Thames basin, UK: Are phosphorus concentrations beginning to limit phytoplankton biomass?
}

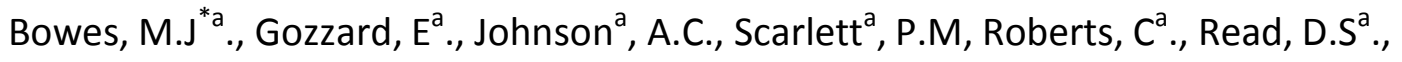 \\ Armstrong, L.K ${ }^{\mathrm{a}}$, Harman, S.A ${ }^{\mathrm{a}}$, Wickham H.D ${ }^{\mathrm{a}}$, \\ ${ }^{a}$ Centre for Ecology and Hydrology, Maclean Building, Crowmarsh Gifford, Wallingford, \\ Oxfordshire, OX10 8BB, UK \\ *Corresponding author. Tel: +44 1491838800, E-mail address: mibo@ceh.ac.uk
}

\section{Abstract}

Chlorophyll- $a$ and nutrient concentrations were monitored at weekly intervals across 21 river sites throughout the River Thames basin, southern England, between 2009 and 2011. Despite a $90 \%$ decrease in soluble reactive phosphorus (SRP) concentration of the lower River Thames since the 1990s, very large phytoplankton blooms still occur. Chlorophyll concentrations were highest in the mid and lower River Thames and the larger tributaries. Lowest chlorophyll concentrations were observed in the smaller tributaries, despite some having very high phosphorus concentrations of over $300 \mu \mathrm{g} \mathrm{l}^{-1}$. There was a strong positive correlation between river length and mean chlorophyll concentration $\left(\mathrm{R}^{2}=0.82\right)$, and rivers connected to canals had ca. six times greater chlorophyll concentration than 'natural' rivers with similar phosphorus concentrations, indicating the importance that residence time has on determining phytoplankton biomass. Phosphorus concentration did have some influence, with phosphorus-enriched rivers having much larger phytoplankton blooms than nutrientpoor rivers of a similar length. Water quality improvements may now be capping chlorophyll 
peaks in the Rivers Thames and Kennet, due to SRP depletion during the spring / early summer phytoplankton bloom period. Dissolved reactive silicon was also depleted to potentially-limiting concentrations for diatom growth in the River Thames during these phytoplankton blooms, but nitrate remained in excess for all rivers throughout the study period. Other potential mitigation measures, such as increasing riparian shading and reducing residence times by removing impoundments may be needed, alongside phosphorus mitigation, to reduce the magnitude of phytoplankton blooms in the future.

Key words: Nutrient; Algae; Phytoplankton; Water quality; River Thames; Eutrophication.

\section{Introduction}

The reduction of nutrient concentrations, and phosphorus concentrations in particular, is seen by catchment managers as a key requirement to deliver good ecological status in waterbodies. The links between the level of nutrient enrichment and algal biomass is well understood for lakes (Canfield, 1983; Vollenweider, 1968). However, the link between phosphorus concentration and algal growth is less clear for rivers and streams (Hilton et al., 2006; Van Nieuwenhuyse and Jones, 1996). Some studies have established strong correlations between phosphorus concentration and algal biomass across ranges of rivers, principally in North America (Chetelat et al., 2006; Van Nieuwenhuyse and Jones, 1996), and these relationships have been used to propose target phosphorus concentrations to control excessive algal growth (Chambers et al., 2011; Dodds et al., 1998). Significant reductions in chlorophyll concentrations (an indicator of phytoplankton biomass) have been observed following reductions in phosphorus concentrations of the River Rhine in The Netherlands and the Sacramento and San Joaquin rivers in California, USA (Van Nieuwenhuyse, 2007), which supports the hypothesis that phosphorus concentration is the key control of phytoplankton 
biomass. Conversely, other studies have shown little relationship between river nutrient concentration and either phytoplankton or periphyton biomass (Bernhardt and Likens, 2004; Figueroa-Nieves et al., 2006; Lewis and McCutchan, 2010; Royer et al., 2008; Yang et al., 2008), and reductions in river phosphorus concentrations in recent years have not resulted in the expected reduction in chlorophyll concentrations (Desortova and Puncochar, 2011; Neal et al., 2006).

There are other physical and biological factors that can affect phytoplankton biomass. Chlorophyll concentrations have been shown to be closely related to residence time and catchment area in many rivers (Neal et al., 2006; Royer et al., 2008; Søballe and Kimmel, 1987). Recent studies have shown the key role that light levels play in determining algal growth rates (Bowes et al., 2012; Hutchins et al., 2010; Munn et al., 2010; Whalen and Benson, 2007). Food web interactions and grazing has also been shown to control riverine algal biomass (Sabater et al., 2008; Twiss et al., 2010).

The River Thames (southern England) has seen major improvements in its water quality since the late 1990s, due principally to improvements in wastewater treatment (Bowes et al., 2010b; Kinniburgh and Barnett, 2010; Neal et al., 2010a). The annual mean soluble reactive phosphorus (SRP) concentration has declined from ca. $1000 \mu \mathrm{g} \mathrm{l^{-1 }}$ in the late 1990 s to ca. 200 $\mu \mathrm{g}^{-1}$ in the late 2000s in the middle reaches of the River Thames, but despite this, maximum chlorophyll concentrations in 2009 were similar in magnitude as those observed from the 1970s to the early 1990s (Bowes et al., 2012; Kinniburgh et al., 1997; Whitehead and Hornberger, 1984). Many of the tributaries of the River Thames have seen similar reductions in phosphorus loading, and it is unknown if this improvement in water quality has resulted in reductions in phytoplankton biomass. 
This paper presents weekly chlorophyll- $a$ and water quality data from a wide range of rivers across the River Thames basin. These were used to investigate the role that nutrient concentration plays in controlling phytoplankton biomass, both spatially (between rivers) and temporally, through each growing season. The hypothesis to be tested was that the magnitude of the maximum chlorophyll- $a$ concentrations at each study site is correlated to its average phosphorus concentration. Other possible controls of phytoplankton biomass, such as the concentration of other macronutrients (nitrogen and silicon) and residence time were also investigated. The water quality data sets were also used to indicate if nutrient limitation (by phosphorus, nitrogen or silicon) was occurring at any of these sites during periods of high phytoplankton biomass.

\subsection{Catchment description}

The River Thames is the largest river wholly in England, with a total length of $354 \mathrm{~km}$ to its tidal limit at Teddington in south west London and a catchment area of $9948 \mathrm{~km}^{2}$ (Marsh and Hannaford, 2008). The Thames basin contains the UK's capital, London, and other major urban centres, including Swindon, Oxford, Slough, Maidenhead and Reading (Figure 1). The basin has a human population density of ca. 960 people $\mathrm{km}^{-2}$ (Merrett, 2007). Despite this high population density, much of the River Thames basin upstream of London is relatively rural (Environment Agency., 2009), with ca. $45 \%$ of land area being classified as arable, 11 $\%$ woodland, $34 \%$ grassland, and only $6 \%$ classed as urban / semi-urban development (Fuller et al., 2002).

The catchment is predominantly underlain by Cretaceous Chalk geology, with areas of impermeable clays in the Enborne, Thame, Ray and Lodden sub-catchments, and Oolitic 
Limestones in the upper catchment. Mean annual rainfall in the lower (Maidenhead), mid (near Oxford) and upper (near the confluence with the River Colne) Thames basin (was 714 mm, $745 \mathrm{~mm}$ and $738 \mathrm{~mm}$ respectively (Marsh and Hannaford, 2008).

\subsection{Study sites}

Monitoring was carried out as part of the Centre for Ecology and Hydrology's Thames Initiative research platform. Sites were located on all 15 major tributaries joining the River Thames between Hannington Wick (site TH) in the upper Thames basin and Slough (on the outskirts of London), and also six sites along the main stem of the River Thames (Figure 1, Table 1). This provided coverage of a wide range of river types, in terms of water quality, flow, land use and sewage input, and covered the majority of the basin above the tidal limit. Most sites were located near to UK Environment Agency flow gauging stations, to provide high-resolution river discharge data. Sampling began in February 2009 at 18 of the study sites, and a further three sites were added to the monitoring programme in late 2009. This paper presents data up until July 2011, and therefore covers three annual algae blooms for most sites.

\section{Methodology}

\subsection{Sampling and chemical analysis}

Bulk water samples were taken at weekly interval from bridges, from the main flow of the river at each monitoring site. Sub-samples were immediately filtered through a $0.45 \mathrm{um}$ cellulose nitrate membrane (WCN grade: Whatman, Maidstone, UK) for subsequent SRP, nitrate and dissolved reactive silicon analysis. Unfiltered sub-samples were taken for chlorophyll-a and total phosphorus (TP). River water temperature was also recorded at the time of sampling. 
On return to the laboratory, the samples were stored at $4^{\circ} \mathrm{C}$ in the dark. Chlorophyll- $a$ samples were filtered and processed within 24-h. The 0.5 litre river water samples were passed through a GF/C grade filter paper (Whatman, Maidstone, UK), and pigment extracted overnight from the suspended solid residue using $90 \%$ acetone. The chlorophyll-a concentration of the extract was then determined spectrophotometrically (Marker et al., 1980). Total phosphorus (TP) was determined by digesting an unfiltered water sample with acidified potassium persulphate in an autoclave at $121^{\circ} \mathrm{C}$ for 40 minutes, then reacting with acid ammonium molybdate reagent to produce a molybdenum-phosphorus complex. This intensely coloured compound was then quantified spectrophotometrically at $880 \mathrm{~nm}$ (Eisenreich et al., 1975). SRP concentration was determined on a filtered sample, using the phosphomolybdenum blue colorimetry method of Murphy and Riley (1962), as modified by Neal et al., (2000a). Samples were analysed within 24 hours, to minimise errors associated with sample instability (House and Warwick, 1998; Jarvie et al., 2002). (SRP is considered equivalent to bioavailable phosphorus (House, 2003)). Dissolved reactive silicon concentration (termed silicon throughout the remaining paper) was determined by reaction with acid ammonium molybdate, to form yellow molybdosilicic acids. These were then reduced using an acidified tin (II) chloride solution to form intensely coloured silicomolybdenum blues, which were quantified spectrophotometrically using a Descrete Analyser (Auto Analyser 2; Seal Analytical, Fareham, UK) (Mullin and Riley, 1955). Nitrate concentration was analysed by ion chromatography (Dionex DX500). 


\section{Results and discussion}

\subsection{Temporal changes in chlorophyll concentration}

Typical temporal variations in chlorophyll-a concentration from across the Thames basin are shown in Figure 2. Sustained phytoplankton blooms occurred between March and July each year at almost all study sites. Similar seasonal patterns in phytoplankton biomass have been observed in other British rivers, such as the River Frome, Dorset (Bowes et al., 2011; House et al., 2001), the Humber basin (Bowes and House, 2001; Neal et al., 2006) and also in previous studies of the Thames basin (Kinniburgh and Barnett, 2010; Kinniburgh et al., 1997; Lack, 1971; Neal et al., 2006; Palmer-Felgate et al., 2008; Whitehead and Hornberger, 1984). Many of these studies have associated this spring / early summer phytoplankton bloom with a proliferation of diatom species, due to the concurrent dip in dissolved reactive silicon concentration. (Diatoms are unicellular algae that bioaccumulate dissolved silicon from the water column to produce a silicate cell wall called a frustule). In the larger rivers (e.g. mid and lower River Thames, River Thame), these blooms were sustained for much of this March to July period, whereas the smaller rivers (e.g. River Cole) had more distinct, shorter duration

peaks in chlorophyll concentration. A second peak in chlorophyll concentration is also observed at a number of sites (e.g River Thames at Wallingford, River Lodden, River Cole) in the late summer / early autumn period (August to October) (Figure 2). Again this has been observed in other British rivers, and again associated with diatom blooms (Bowes et al., 2009).

It is unclear why the phytoplankton blooms are not sustained through the July to August summer period at any of the monitoring sites (Figure 2), and chlorophyll- $a$ concentrations remain very low through this period, when conditions seem ideal for algal growth. Water temperatures, nutrient concentrations, light intensity and day length are at their greatest and 
low river flows result in long residence times (Figure 3). The decline in chlorophyll- $a$ could be due to a phytoplankton community shift that is dominated by algae that have photosynthetic pigments other than chlorophyll-a. It could also be due to temperature limitation. Studies of the River Frome in Dorset, southern England showed that diatom growth rates (as indicated by depressed dissolved reactive silicon concentrations) declined when water temperatures reached $15{ }^{\circ} \mathrm{C}$ (Bowes et al., 2011). Data from this study infers a similar temperature limitation effect during summer in all rivers, with dissolved reactive silicon concentration dips and chlorophyll peaks suddenly ceasing when temperatures (ranging from 15 to $21^{\circ} \mathrm{C}$ across the study sites) are reached. Alternatively, the apparent decline in phytoplankton could be due to grazing / foodweb interactions, with predator populations increasing during the summer period, in response to the algal bloom.

The one exception to this regular seasonal pattern was the River Leach (the site with the lowest phosphorus concentrations within this study), which showed no increase in chlorophyll concentration through the spring to early summer periods, and only had intermittent chlorophyll peaks in the autumn / winter periods (Figure 2), some corresponding to high flow events. This implies that the phytoplankton biomass is negligible in this small, phosphorus-poor stream, and the benthic algal community dominates. This benthic biomass was probably released into the water column outside the growing period due to sloughing at higher water velocities, resulting in the observed chlorophyll peaks.

There was a distinct pattern in chlorophyll concentrations through the three algae growing seasons of this study. The monitoring period was characterized by high chlorophyll concentrations in the larger rivers in both 2009 and 2011, and relatively low chlorophyll concentrations in 2010 (Table 1; Figure 2). Almost all of the smaller tributary sites had their 
largest annual peak in either 2009 or 2011 (except the Rivers Enborne and Coln), and many sites had a two-fold reduction in chlorophyll- $a$ in 2010 , compared to these maximum values observed in 2009 or 2011. Maximum chlorophyll concentrations in the mid to lower Thames sites (Wallingford, Sonning and Runnymede) for 2009 and 2011 reached ca. $300 \mu \mathrm{g} \mathrm{l}^{-1}$ (Table 1), which were typical of values observed throughout the period 1980 to 1996 for the River Thames at Reading (Kinniburgh and Barnett, 2010; Kinniburgh et al., 1997) when maximum SRP concentrations in some years were $>4000 \mu \mathrm{g} \mathrm{l^{-1 }}$. Similar annual patterns were also observed in the upper River Thames at Newbridge, and the Rivers Cherwell and Cole (Figure 2). The smaller tributaries had much less year-to-year variation in maximum chlorophyll concentration.

The reasons for the significant contrast between the major phytoplankton blooms in 2009 and 2011, and much smaller bloom in 2010 , is unclear. The maximum water temperature and river flows during the summer periods were similar across the three years (Figure 3). However, there were significant differences in river conditions during the spring period, when the phytoplankton bloom was at its height. At the beginning of May, water temperature in the lower River Thames (Runnymede) was 17.0 and $15.3^{\circ} \mathrm{C}$ in 2009 and 2011 respectively, but only $12.2^{\circ} \mathrm{C}$ in 2010 . The river discharges were also significantly different at this time (25.7 and $20.3 \mathrm{~m}^{3} \mathrm{~s}^{-1}$ in 2009 and 2011 respectively, and $46.4 \mathrm{~m}^{3} \mathrm{~s}^{-1}$ in 2010). This suggests that major river phytoplankton blooms may result from warm spring periods (possibly related to high light levels), and low river flow velocities which will increase residence times and reduce scouring of benthic biofilms. Similar conclusions on the effect of river flow on phytoplankton biomass have been made in previous studies of the Rivers Thames and Kennet (Lack, 1971). Further studies need to be conducted over longer timescales to investigate this 
potential relationship between chlorophyll concentrations and flow, temperature and light during this critical spring period.

\subsection{Spatial pattern in chlorophyll concentrations}

The largest average and maximum chlorophyll concentrations were observed in the mid and lower River Thames (from Newbridge to Runnymede), and the four tributaries in the mid Thames catchment around Oxford (the Rivers Cherwell, Ray, Evenlode and Thame) (Figure 4a). The sites with the lowest average and maximum chlorophyll concentrations are the relatively short tributaries of less than $30 \mathrm{~km}$; the Rivers Wye, Pang, Leach and Enborne. The upper River Thames at Hannington Wick, and the Rivers Windrush and Lodden also had low phytoplankton biomass.

For the main stem of the River Thames, there was a general increase in chlorophyll concentration downstream for each study year, with the upper Thames at Hannington Wick always having the lowest chlorophyll concentration, and the Thames at Wallingford and Runnymede having the maximum concentrations (Table 1). Similar increases in plankton biomass along a river continuum have been observed in previous studies of the Sacramento River, USA (Greenberg, 1964) and the Seine, France (Garnier et al., 1995). This supports the theories of Hilton et al., (2006) and Neal et al., (2006) that the residence time of a waterbody is the dominant control on phytoplankton abundance. However, there was not a simple relationship between chlorophyll concentration and distance downstream along the River Thames, and the Thames sites at Swinford and Sonning both showed decreases in chlorophyll concentration, compared with the Thames monitoring sites directly upstream (Newbridge and Wallingford). The reduction in phytoplankton abundance between the monitoring sites at Wallingford and Sonning, and Newbridge and Swinford, are probably due to the input of 
low-chlorophyll-concentration water from the tributaries joining the Thames (the Rivers Kennet and Pang, and the River Windrush, respectively) (Figure 4a).

\subsection{Links between nutrient concentrations and phytoplankton biomass}

The spatial distribution of soluble reactive phosphorus concentrations across the Thames basin are shown in Figure 4b. The highest average SRP concentrations (>400 $\mu \mathrm{g} \mathrm{l}^{-1}$ ) were observed in some of the tributaries of the mid and lower Thames basin; the Rivers Ray, Cut and Thame. These sites are closely associated with high sewage treatment works (STW) loadings from the towns of Bicester (population estimate of 31600 ), Bracknell (population estimate of 71600 ) and Aylesbury (population estimate of 88 900) respectively. The lowest SRP and TP concentrations were observed in the relatively rural sub-catchments of the upper Thames basin (the River Leach, Coln and Windrush), and the River Kennet and Pang, draining the south-western section of the basin. The Kennet and Pang sub-catchments are also relatively rural, but the Kennet sub-catchment contains a number of significant towns and their associated sewage treatment works. However, much of the River Kennet has been designated as a Site of Special Scientific Interest, due to its rare assemblages of flora and fauna, and has already introduced high levels of wastewater treatment and phosphate removal at all its significant STWs (Neal et al., 2010b). This demonstrates how comprehensive point and diffuse nutrient mitigation measures can significantly reduce phosphorus concentrations in UK rivers, and may indicate what is possible for the other tributaries in the Thames basin in the future.

Nitrate concentrations were high throughout the Thames basin, with most study sites having average concentrations between 23 and $37 \mathrm{mg} \mathrm{l}^{-1} \mathrm{NO}_{3}$ (Table 1). These high nitrate concentrations are probably due to the legacy of agricultural pollution that has contaminated the groundwater that provides most of the river flow to these Chalk and limestone rivers, 
particularly during summer low flow periods. The lowest average nitrate concentrations were observed in the Rivers Cole and Enborne (19.5 and $17.1 \mathrm{mg} \mathrm{l}^{-1}$ respectively), which are underlain by clay deposits, thereby reducing the transfer of nitrate pollution from the groundwater to the river. The Cut at Paley Street had over twice the $\mathrm{NO}_{3}$ concentration of any other river within the study, with an average concentration of $86 \mathrm{mg} \mathrm{l}^{-1}$ and a maximum value of $151 \mathrm{mg} \mathrm{l}^{-1} \mathrm{NO}_{3}$. This extremely high nitrate loading is almost certainly derived from the major STW inputs to this relatively small river from Bracknell STW (population estimate of 71600 ). The next highest nitrate concentrations were observed in the River Ray at Islip and the River Thame at Wheatley. Again, both of these rivers receive significant sewage effluent inputs, resulting in high levels of both nitrate and phosphorus enrichment.

There are few clear similarities between the spatial pattern of chlorophyll and nutrient concentrations (Figure 4). The sites with maximum chlorophyll concentrations above 200 $\mathrm{mg}^{-1}$ (the mid and lower River Thames and the River Cherwell) all have relatively modest (in the context of this study) SRP concentrations of between 109 and $201 \mu \mathrm{g} \mathrm{l}^{-1}$ and nitrate concentrations of between 25 and $30 \mathrm{mg} \mathrm{l}^{-1} \mathrm{NO}_{3}$ Some of the most heavily nutrient-enriched sites (the Rivers Ock, Cole, Wye and The Cut) have very low average chlorophyll concentrations of less than $10 \mu \mathrm{g}^{-1}$. However, there are some correlations that imply that there is a link between phytoplankton biomass and nutrient concentration. The five sites with SRP and TP concentrations below $100 \mu \mathrm{g} \mathrm{l}^{-1}$ (the River Leach, Kennet, Pang, Coln and Windrush) have some of the lowest average chlorophyll concentrations of less than $10 \mu \mathrm{g}^{-1}$. SRP concentrations of between 60 and $100 \mu \mathrm{g} \mathrm{l}^{-1}$ have been identified as being growthlimiting to benthic biofilms during in-stream mesocosm studies of UK chalk rivers (Bowes et al., 2012; Bowes et al., 2010a; Bowes et al., 2007), and therefore the relatively low P concentrations at these sites may be reducing phytoplankton biomass. Conversely, two of the 
three most phosphorus-enriched tributaries, the River Thame and Ray, also have some of the highest maximum and average chlorophyll concentrations.

Despite some apparent links between chlorophyll and phosphorus enrichment described above, there is no simple correlation between the maximum chlorophyll concentration observed within the monitoring period and the average total phosphorus concentration at each study site (Figure 5) ( $\mathrm{R}^{2}$ of 0.004$)$. However, there appears to be two distinct patterns within this relationship (Figure 5). The chlorophyll concentrations of sites on the middle and lower Thames, and the River Cherwell correlate closely with TP concentration ( $\mathrm{R}^{2}$ of 0.79 ), and have much higher phytoplankton biomass for a particular TP concentration than the remaining sites. These sites (plus the River Kennet) are all used extensively for boating, and are interconnected with adjacent canals, and also have extensive lock systems and weirs built into the river. These dead zones will greatly increase the residence time of the river water, and thereby allow time for the phytoplankton to reproduce as it slowly travels downstream (Reynolds, 2000). Connection of these dead zones to the main channel will also provide a constant source of algal inoculum to the river. This conclusion is further supported by the data for the River Thames at Hannington Wick, which lies within the "natural" river cluster in Figure 5, despite all the other River Thames sites being within the "rivers with canals" relationship. This is because the Hannington Wick site is upstream of the navigable part of the River Thames, and therefore does not have locks and associated flow impediments. (The River Thames is navigable up to the confluence with the River Coln). The relationship between TP and chlorophyll for the "rivers with canals" subset is very similar to the TP / chlorophyll relationship observed for temperate lakes by Van Nieuwenhuyse et al., (1996). 


\subsection{Effect of residence time on phytoplankton biomass}

The distance from the monitoring site to the river source was used as an approximate indicator of residence time within each river (Table 1). The distances to source were calculated using a GIS application, the Centre for Ecology and Hydrology's Intelligent River Network (Dawson et al., 2002) There was a strong correlation between upstream river length and average chlorophyll concentration (between February 2009 to July 2011) (Figure 6) $\left(\mathrm{R}^{2}=\right.$ 0.82). Distance to source was also closely correlated with the maximum observed chlorophyll concentration throughout the 30 month monitoring period.

Maximum chlorophyll concentration $=(1.7728 \times$ Distance to source $)-10.121\left(R^{2}=0.70\right)$.

Residence time therefore has a major impact on phytoplankton biomass in the Thames basin. The strong link between chlorophyll concentration and residence time has been made in previous studies of the Thames (Neal et al., 2006) and other rivers (Greenberg, 1964). However, phosphorus concentrations also appeared to have some control on phytoplankton biomass, from observing the increased chlorophyll levels present in some of the more nutrient-enriched tributaries, such as the River Ray and Thame. Previous studies have also shown that other chemical determinands, such as dissolved reactive silicon and nitrate concentration, could also control phytoplankton biomass. Stepwise regression analysis was applied to the complete data set, using Minitab statistical software, release 15, (Minitab Inc., State College, Pennsylvania, USA) which showed that distance to source and SRP concentration produced the strongest model to predict maximum observed chlorophyll concentrations during the monitoring period. Adding the SRP concentration to the distanceto-source regression model increased the $\mathrm{R}^{2}$ from 0.70 to 0.74 , and the adjusted $\mathrm{R}^{2}$ from 0.69 to 0.71 . Adding TP as an alternative second independent variable raised the $\mathrm{R}^{2}$ by a similar 
amount. The addition of other determinands within the data set (average TP, nitrate and dissolved reactive silicon concentrations, average river flow) as a third variable in the distance-to-source / SRP concentration regression model did not improve the prediction of maximum chlorophyll concentration, producing reductions in the adjusted $\mathrm{R}^{2}$ values. This shows that river length has by far the greatest effect on the size of the phytoplankton bloom in these rivers, with phosphorus concentration also playing a minor role.

To visualize how phosphorus concentrations specifically affect chlorophyll concentrations, rivers of similar length were extracted from the data set. Figure 7 shows chlorophyll timeseries data for 2009 for the five monitoring sites that were ca. $30 \mathrm{~km}( \pm 2 \mathrm{~km})$ from the river source. The most phosphorus-enriched river, the River Ray (average TP in $2009=548 \mu \mathrm{g} \mathrm{l}^{-}$

${ }^{1}$ ) had by far the highest maximum and average chlorophyll concentrations (110 and $20.8 \mu \mathrm{g}$ $1^{-1}$ respectively). The River Ock and Cole (TP concentrations of 316 and 319 respectively) had the next highest average chlorophyll concentrations (5.6 and $10.0 \mu \mathrm{g} \mathrm{l}^{-1}$ ), with very similar concentrations through the March to June period. The river with the lowest average TP concentration, the River Leach (average TP concentration $=31 \mu \mathrm{g} 1^{-1}$ ), had the lowest average chlorophyll concentration $\left(2.8 \mu \mathrm{g} \mathrm{l}^{-1}\right)$, and did not appear to have a phytoplankton bloom during the spring and summer period of 2009. The five rivers of ca. $50 \mathrm{~km}( \pm 8 \mathrm{~km})$ length also showed a similar strong correlation between maximum chlorophyll concentration and average TP concentration $\left(\mathrm{R}^{2}=0.71\right)$.

\subsection{Nutrient limitation of phytoplankton blooms}

Previous studies have shown that during the phytoplankton blooms that occurred annually in the River Thames between 1980 and 1996, maximum chlorophyll concentrations at the town of Reading were always ca. 250 to $350 \mu \mathrm{g} \mathrm{l}^{-1}$, and never exceeded $370 \mu \mathrm{g} \mathrm{l}^{-1}$ (Kinniburgh and 
Barnett, 2010; Kinniburgh et al., 1997). This present study observed a similar magnitude of blooms in 2009 and 2011. It would seem plausible that chlorophyll concentrations would sometimes attain even higher concentrations, particularly when such a rapid increase in chlorophyll level is observed at the onset of each bloom. The consistency of the maximum chlorophyll concentration values during major blooms imply that phytoplankton biomass in the River Thames is controlled or limited by a factor or resource that restricts the magnitude of the biomass to below $370 \mu \mathrm{g} 1^{-1}$ chlorophyll. One possible explanation for these consistent maximum chlorophyll concentrations could be due to self-shading. When the biomass of phytoplankton reaches this concentration, the algae in the lower part of the water column may become light-limited, due to shading by the phytoplankton in the upper water layers (Whitehead and Hornberger, 1984). Another explanation could be silicon limitation of the algae. Previous studies have highlighted the role that dissolved reactive silicon plays in limiting diatom biomass in the Thames (Lack, 1971; Neal et al., 2000b), and depletion of dissolved silicon from the water column is a likely reason that phytoplankton blooms have never exceeded $370 \mu \mathrm{g}^{-1}$ in the mid and lower River Thames.

\subsubsection{River Thames}

Reductions in dissolved reactive silicon concentration are observed at almost all study sites within the Thames basin, and coincide with peaks in chlorophyll concentration (Figure 8). This confirms that the annual phytoplankton blooms in March to June, and the secondary blooms in August to September that occur at some of the monitoring sites, have a large diatom component. The algal blooms in the River Thames at Swinford between 2009 and 2011 each resulted in the dissolved reactive silicon concentration reducing from ca. $3.5 \mathrm{mg}^{-1}$ to ca. $0.5 \mathrm{mg} \mathrm{l}^{-1}$ (Figure 8). SRP concentrations also declined, due to bioaccumulation by the phytoplankton, but did not fall below $25 \mathrm{gg} \mathrm{l}^{-1}$, and nitrate remained above $17 \mathrm{mg} \mathrm{l}^{-1}$. 
Therefore, dissolved reactive silicon was becoming scarce, but none of these three macronutrients would be likely to limit phytoplankton growth at these concentrations.

A further $45 \mathrm{~km}$ downstream at Wallingford, the dissolved reactive silicon concentrations of the River Thames dropped to as low as $0.1 \mathrm{mg}^{-1}$ during the major chlorophyll peaks in both the spring of 2009 and 2011, and also the autumn bloom in 2010. In addition, SRP concentrations were reduced to 14 and $23 \mu \mathrm{g} \mathrm{l}^{-1}$ during the 2009 and 2011 chlorophyll peaks. Therefore, both $\mathrm{P}$ and $\mathrm{Si}$ were simultaneously in such short supply during these one-week periods that the growth rate of phytoplankton biomass would likely to be silicon limited, and possible phosphorus limited too. However, the SRP concentration only began to become exhausted when the chlorophyll concentrations had already reached $200 \mu \mathrm{g} \mathrm{l^{-1 }}$. A further 32 $\mathrm{km}$ downstream of Wallingford at Sonning, SRP concentrations were reduced to below $5 \mu \mathrm{g}$ $1^{-1}$ in the River Thames for three and four week periods during the 2009 and 2011 blooms respectively. Dissolved reactive silicon concentration is also reduced, but remains relatively high (minimum concentration of $1.4 \mathrm{mg} \mathrm{l}^{-1}$ ). This is probably due to the major input of high silicon concentration water from the River Kennet, the largest tributary within this study area, which enters the River Thames ca. $3 \mathrm{~km}$ upstream of the Sonning monitoring site (Figure 1). Therefore, phytoplankton growth appears to be phosphorus limited at this site, but again, phosphorus only becomes limiting when the phytoplankton bloom is already well established and chlorophyll concentrations are over $200 \mu \mathrm{g} \mathrm{l}^{-1}$.

At the downstream extent of the study area (the River Thames at Runnymede) the phosphorus concentration during the 2009 and 2011 phytoplankton blooms was reduced to $<7 \mu \mathrm{g}^{-1}$ for periods of seven and four weeks respectively. During these periods, dissolved reactive silicon concentration was also reduced to below $0.1 \mathrm{mg} \mathrm{l}^{-1}$, and so the phytoplankton biomass 
of the Thames was being capped by a lack of both phosphorus and silicon. During the smaller chlorophyll peak of 2010, phosphorus alone was depleted below detectable concentrations. The data from the three phytoplankton blooms suggest that due to the rapid reductions in phosphorus loading in the River Thames since the late 1990s, phosphorus is now becoming the principle limiting factor in capping blooms to ca. $300 \mu \mathrm{g}^{-1}$ chlorophyll in the lower Thames, rather than silicon. This indicates that if phosphorus concentrations can be lowered further in the River Thames, the periods of phosphorus depletion will increase, and the typical maximum chlorophyll concentrations of ca. $300 \mu \mathrm{g} \mathrm{l}^{-1}$ that have been observed in the mid and lower River Thames since 1980 may begin to be reduced due to P limitation.

However, it is important to note that SRP concentration is only reduced to potentiallylimiting concentrations in the River Thames due to bioaccumulation by the phytoplankton bloom, and so algal growth-limitation only occurs once the bloom is well established. Reducing the lower River Thames SRP concentration (at the onset of each annual bloom) to a potentially-limiting concentration of ca. $80 \mu \mathrm{g} \mathrm{l}^{-1}$ (as identified by Thames phosphoruslimitation experiments by Bowes and co-workers (2012)) may be required to substantially reduce the magnitude of the algal blooms. This would be extremely costly to achieve, as it would require increased levels of P removal at a large number of STWs and possibly major land-use changes. It could be more effective to target phosphorus mitigation in the upper River Thames and upper tributaries, as this would slow the development of the bloom as it moved along the river continuum. Also, because phosphorus loads in the upper Thames are much smaller than the lower Thames, the targeted introduction of $\mathrm{P}$ removal at selected STWs in the upper basin could more easily reduce SRP concentrations to algae-limiting concentrations. 


\subsubsection{River Kennet}

Data from the River Kennet in particular implies that phosphorus has begun to restrict the size of the phytoplankton bloom. By applying the linear regression for rivers connected to canals (Figure 5), it can be estimated that the River Kennet would have produced a maximum chlorophyll concentration of ca. $170 \mu \mathrm{g} \mathrm{l} \mathrm{l}^{-1}$ if the average SRP concentration had remained at its 2002 to 2006 levels of ca. $150 \mu \mathrm{g} \mathrm{l}^{-1}$, rather than the $45 \mu \mathrm{g} \mathrm{l^{-1 }}$ maximum chlorophyll concentration observed in this study. Perhaps the strongest evidence for phosphorus limitation of the phytoplankton bloom in the River Kennet is from examining the phosphorus monitoring data (Figure 9), which shows that SRP was reduced to below $10 \mu \mathrm{g} \mathrm{l}^{-1}$ for six weeks in the spring and summer of 2010, and seven times during the spring and early summer of 2011 (from ca. $50 \mu \mathrm{g} \mathrm{l}^{-1}$ in early spring). These periods of very low SRP concentration coincided with peaks in chlorophyll concentration. Dissolved reactive silicon concentrations dipped sharply (again coinciding with chlorophyll concentration peaks), but remained at relatively high concentrations ( $>4.5 \mathrm{mg} \mathrm{l}^{-1}$ silicon). Previous phosphorus limitation studies on the upper River Kennet have shown that SRP concentrations of less than $60 \mu \mathrm{g}^{-1}$ begin to limit algae, and algal growth rate is reduced by a third when SRP concentrations are reduced to $30 \mu \mathrm{g} \mathrm{l}^{-1}$ (Bowes et al., 2010a). Therefore, SRP concentrations of less than $10 \mu \mathrm{g} \mathrm{l}^{-1}$ must significantly reduce the ability of phytoplankton to grow and reproduce. This is strong evidence that the phytoplankton bloom in the lower River Kennet at Woolhampton is now being limited by phosphorus concentration.

\section{Conclusions}

- This study has shown that the average chlorophyll concentrations observed in rivers across the Thames basin are very closely associated with river length, indicating that 
water residence time, and not phosphorus concentration, is the key variable in determining phytoplankton biomass.

- Rivers that are connected to canals, or have extensive lock systems, have ca. six times higher maximum chlorophyll concentrations than rivers that do not have such impoundments with the same phosphorus concentration (Figure 5), which further demonstrates the importance of residence time on phytoplankton biomass. Removing impoundments and dead-zones, and stopping water transfers between rivers and canals may be an effective way for catchment managers to reduce phytoplankton blooms and to improve river ecology. These relationships between river length and degree of impoundment with chlorophyll concentration indicate that changing the physical, rather than the chemical conditions of a river could be a more effective means of controlling excessive phytoplankton growth.

- River phosphorus concentration does play a role in determining both maximum and average chlorophyll concentrations. Phosphorus-enriched rivers have larger phytoplankton blooms than nutrient-poor rivers of a similar length.

- Reductions in phosphorus concentration in the River Thames may now be beginning to restrict and cap the size of phytoplankton blooms in the mid and lower River Thames, due to phosphorus limitation, as $\mathrm{P}$ is becoming depleted for periods of up to four weeks during the spring and early summer phytoplankton-bloom period. Prior to these water quality improvements, blooms appear to have been capped by the exhaustion of the dissolved reactive silicon supply alone. As further reductions of phosphorus loadings to the River Thames are made, to comply with the European Union's Water Framework Directive, this period of phosphorus exhaustion will increase, and the maximum chlorophyll concentrations (of around $300 \mu \mathrm{g}^{-1}$ ) that have been regularly observed since the 1980s may begin to be reduced, due to this 
algal phosphorus-limitation / phosphorus-silicon co-limitation during the late spring / early summer period.

- Nitrate concentrations remain high throughout the annual cycle for all monitoring sites, and there was no link between $\mathrm{NO}_{3}$ concentration and either average or maximum chlorophyll concentrations, indicating that phytoplankton were not nitrogen-limited in any of the rivers in this study. Therefore, mitigation measures that only deliver reduced nitrate concentrations in the Thames basin will have no impact on phytoplankton blooms.

- The River Kennet also has extended periods (up to 7 weeks during the spring to early summer algae growing season) where phosphorus concentrations were very low (below $10 \mu \mathrm{g} \mathrm{l}^{-1}$ ), following a major improvement in water quality since the late 1990s. Despite this river being directly connected at multiple locations to the adjacent Kennet and Avon Canal, and being the longest tributary in the study (both of which will greatly increase the residence time), it has relatively low chlorophyll concentrations. This indicates that the lack of phosphorus through the growing season is now limiting phytoplankton growth, and the reduction in phosphorus loading could be delivering lower algal blooms in the River Kennet.

The River Kennet may provide a template for catchment managers, and shows what is possible when phosphorus concentrations in the rivers of the Thames basin are reduced to potentially-limiting concentrations. However, reducing the pre-bloom SRP concentration of the mid to lower River Thames from $>200 \mu \mathrm{g} \mathrm{l}^{-1}$ to the potentially growth-limiting concentration of $80 \mu^{-1}$ (Bowes et al., 2012) will be extremely costly and potentially difficult to achieve. Other potential mitigation measures, such as increasing the riparian tree 
shading in the upper river (which could have the potential to reduce algal growth rate in the River Thames by up to 50\% (Bowes et al., 2012)) and reducing residence time by removing impoundments and connections to canals may be needed, alongside phosphorus mitigation, to reduce the magnitude of phytoplankton blooms and to deliver good ecological status in the future.

\section{List of Figures}

Table 1. Monitoring site locations with mean nutrient concentrations and discharge data through the monitoring period, and maximum chlorophyll-a concentrations observed in each individual year.

Figure 1. Map of study area. A key to the study site codes are given in Table 1.

Figure 2. Time-series of chlorophyll- $a$ concentrations at selected study sites.

Figure 3. River flow and water temperature at the time of sampling for the River Thames at Runnymede.

Figure 4. Maps of (a) maximum observed chlorophyll- $a$ concentrations and (b) average total phosphorus concentrations during the 2009 to 2011 monitoring period.

Figure 5. Relationship between the average total phosphorus concentration and the maximum chlorophyll- $a$ concentration observed during the monitoring period. $\mathrm{X}=$ rivers that are connected to canals or contain locks. Study-site codes are given in Table 1. 
Figure 6. Relationship between average chlorophyll- $a$ concentration throughout the monitoring period and the distance from the monitoring site to the river source. The average total phosphorus (TP) concentrations for each river are given in the legend.

Figure 7. Chlorophyll- $a$ concentration time-series for all monitoring sites that were $30 \mathrm{~km}$ from the river source.

Figure 8 a. Soluble reactive phosphorus, nitrate, dissolved reactive silicon and chlorophyll- $a$ time-series for sites along the River Thames at Swinford and Wallingford from Feb 2009 to July 2011.

Figure $8 \mathrm{~b}$. Soluble reactive phosphorus, nitrate, dissolved reactive silicon and chlorophyll- $a$ time-series for sites along the River Thames at Sonning and Runnymede, from Feb 2009 to July 2011.

Figure 9. Time-series of soluble reactive phosphorus, dissolved reactive silicon and chlorophyll- $a$ concentrations for the River Kennet at Woolhampton, from November 2009 to July 2011.

\section{Acknowledgements}

This study was funded by the Natural Environment Research Council. We would like to thank all those people who have helped with the extensive sampling and analysis required within this project, including Jonathan Newman, Alan Warwick, Cyril Barrett, Margaret Neal, Gearoid Webb and Emily Carr. We would also like to thank the Environment Agency and the CEH National River Flow Archive for supplying the river flow data.

\section{References}


Bernhardt ES, Likens GE. Controls on periphyton biomass in heterotrophic streams. Freshwater Biology 2004; 49: 14-27.

Bowes MJ, House WA. Phosphorus and dissolved silicon dynamics in the River Swale catchment, UK: a mass-balance approach. Hydrological Processes 2001; 15: 261-280.

Bowes MJ, Ings NL, McCall SJ, Warwick A, Barrett C, Wickham HD, et al. Nutrient and light limitation of periphyton in the River Thames: Implications for catchment management. Science of the Total Environment 2012.

Bowes MJ, Lehmann K, Jarvie HP, Singer AC. Investigating periphyton response to changing phosphorus concentrations in UK rivers using within-river flumes. British Hydrological Society International Conference, University of Newcastle-upon-Tyne, 2010a, pp. 6.

Bowes MJ, Neal C, Jarvie HP, Smith JT, Davies HN. Predicting phosphorus concentrations in British rivers resulting from the introduction of improved phosphorus removal from sewage effluent. Science of the Total Environment 2010b; 408: 4239-4250.

Bowes MJ, Smith JT, Hilton J, Sturt MM, Armitage PD. Periphyton biomass response to changing phosphorus concentrations in a nutrient-impacted river: a new methodology for phosphorus target setting. Canadian Journal of Fisheries and Aquatic Sciences 2007; 64: 227-238.

Bowes MJ, Smith JT, Neal C. The value of high-resolution nutrient monitoring: A case study of the River Frome, Dorset, UK. Journal of Hydrology 2009; 378: 82-96.

Bowes MJ, Smith JT, Neal C, Leach DV, Scarlett PM, Wickham HD, et al. Changes in water quality of the River Frome (UK) from 1965 to 2009: Is phosphorus mitigation finally working? Science of the Total Environment 2011; 409: 3418-3430.

Canfield DE. Prediction of chlorophyll a concentrations in Florida lakes - The importance of phosphorus and nitrogen. Water Resources Bulletin 1983; 19: 255-262.

Chambers PA, McGoldrick DJ, Brua RB, Vis C, Culp JM, Benoy GA. Development of environmental thresholds for nitrogen and phosphorus in streams. Journal of Environmental Quality 2011; 40.

Chetelat J, Pick FR, Hamilton PB. Potamoplankton size structure and taxonomic composition: Influence of river size and nutrient concentrations. Limnology and Oceanography 2006; 51 : 681-689.

Dawson FH, Hornby DD, Hilton J. A method for the automated extraction of environmental variables to help the classification of rivers in Britain. Aquatic Conservation-Marine and Freshwater Ecosystems 2002; 12: 391-403.

Desortova B, Puncochar P. Variability of phytoplankton biomass in a lowland river: Response to climate conditions. Limnologica 2011; 41: 160-166.

Dodds WK, Jones JR, Welch EB. Suggested classification of stream trophic state: Distributions of temperate stream types by chlorophyll, total nitrogen, and phosphorus. Water Research 1998; 32: 1455-1462.

Eisenreich SJ, Bannerman RT, Armstrong DE. A simplified phosphorus analytical technique. Environmental Letters 1975; 9: 45-53.

Environment_Agency. River Basin Management Plan. Thames River Basin District. Environment Agency, Bristol, UK, 2009, pp. 89.

Figueroa-Nieves D, Royer TV, David MB. Controls on chlorophyll-a in nutrient-rich agricultural streams in Illinois, USA. Hydrobiologia 2006; 568: 287-298.

Fuller RM, Smith GM, Sanderson JM, Hill RA, Thomson AG. The UK Land Cover Map 2000: Construction of a parcel-based vector map from satellite images. Cartographic Journal 2002; 39: 15-25.

Garnier J, Billen G, Coste M. Seasonal Succession of Diatoms and Chlorophyceae in the Drainage Network of the Seine River: Observations and Modeling. Limnology and Oceanography 1995; 40: 750-765.

Greenberg AE. Plankton of the Sacramento River. Ecology 1964; 45: 40-49. 
Hilton J, O'Hare M, Bowes MJ, Jones JI. How green is my river? A new paradigm of eutrophication in rivers. Science of the Total Environment 2006; 365: 66-83.

House WA. Geochemical cycling of phosphorus in rivers. Applied Geochemistry 2003; 18: 739-748.

House WA, Leach DV, Armitage PD. Study of dissolved silicon and nitrate dynamics in a freshwater stream. Water Research 2001; 35: 2749-2757.

House WA, Warwick MS. Intensive measurements of nutrient dynamics in the River Swale. Science of the Total Environment 1998; 210: 111-137.

Hutchins MG, Johnson AC, Deflandre-Vlandas A, Comber S, Posen P, Boorman D. Which offers more scope to suppress river phytoplankton blooms: Reducing nutrient pollution or riparian shading? Science of the Total Environment 2010; 408: 5065-5077.

Jarvie HP, Withers PJA, Neal C. Review of robust measurement of phosphorus in river water: sampling, storage, fractionation and sensitivity. Hydrology and Earth System Sciences 2002; 6: 113-131.

Kinniburgh JH, Barnett M. Orthophosphate concentrations in the River Thames: reductions in the past decade. Water and Environment Journal 2010; 24: 107-115.

Kinniburgh JH, Tinsley MR, Bennett J. Orthophosphate Concentrations in the River Thames. Water and Environment Journal 1997; 11: 178-185.

Lack TJ. Quantitative studies on the phytoplankton of the Rivers Thames and Kennet at Reading. Freshwater Biology 1971; 1: 213-224.

Lewis WM, Jr., McCutchan JH, Jr. Ecological responses to nutrients in streams and rivers of the Colorado mountains and foothills. Freshwater Biology 2010; 55: 1973-1983.

Marker AFH, Nusch EA, Rai H, Riemann B. The measurement of photosynthetic pigments in freshwaters and standardisation of methods: Conclusions and recommendations. Arch. Hydrobiol. Beih. 1980; 14: 91-106.

Marsh TJ, Hannaford J. UK Hydrometric Register. Hydrological data UK series. Centre for Ecology and Hydrology, 2008, pp. 210.

Merrett S. The Thames catchment: a river basin at the tipping point. Water Policy 2007; 9: 393-404.

Mullin JB, Riley JP. The colourometric determination of silicate with special reference to sea and natural waters. Analytica chimica acta 1955; 12: 31-36.

Munn M, Frey J, Tesoriero A. The Influence of Nutrients and Physical Habitat in Regulating Algal Biomass in Agricultural Streams. Environmental Management 2010; 45: 603-615.

Murphy J, Riley JP. A modified single solution method for the determination of phosphorus in natural waters. Analytica chemica acta 1962; 12: 31-36.

Neal C, Hilton J, Wade AJ, Neal M, Wickham H. Chlorophyll-a in the rivers of eastern England. Science of the Total Environment 2006; 365: 84-104.

Neal C, Jarvie HP, Williams R, Love A, Neal M, Wickham $H$, et al. Declines in phosphorus concentration in the upper River Thames (UK): Links to sewage effluent cleanup and extended end-member mixing analysis. Science of the Total Environment 2010a; 408: 13151330.

Neal C, Martin E, Neal M, Hallett J, Wickham HD, Harman SA, et al. Sewage effluent clean-up reduces phosphorus but not phytoplankton in lowland chalk stream (River Kennet, UK) impacted by water mixing from adjacent canal. Sci Total Environ 2010b; 408: 5306-16.

Neal C, Neal M, Wickham H. Phosphate measurement in natural waters: two examples of analytical problems associated with silica interference using phosphomolybdic acid methodologies. Science of the Total Environment 2000a; 251: 511-522.

Neal C, Williams RJ, Neal M, Bhardwaj LC, Wickham H, Harrow M, et al. The water quality of the River Thames at a rural site downstream of Oxford. Science of the Total Environment 2000b; 251: 441-457.

Palmer-Felgate EJ, Jarvie HP, Williams RJ, Mortimer RJG, Loewenthal M, Neal C. Phosphorus dynamics and productivity in a sewage-impacted lowland chalk stream. Journal of Hydrology 2008; 351: 87-97. 
Reynolds CS. Hydroecology of river plankton: the role of variability in channel flow. Hydrological Processes 2000; 14: 3119-3132.

Royer TV, David MB, Gentry LE, Mitchell CA, Starks KM, Heatherly T, et al. Assessment of chlorophylla as a criterion for establishing nutrient standards in the streams and rivers of illinois. Journal of Environmental Quality 2008; 37: 437-447.

Sabater S, Artigas J, Duran C, Pardos M, Romani AM, Tornes E, et al. Longitudinal development of chlorophyll and phytoplankton assemblages in a regulated large river (the Ebro River). Science of the Total Environment 2008; 404: 196-206.

Søballe DM, Kimmel BL. A Large-Scale Comparison of Factors Influencing Phytoplankton Abundance in Rivers, Lakes, and Impoundments. Ecology 1987; 68: 1943-1954.

Twiss MR, Ulrich C, Kring SA, Harold J, Williams MR. Plankton dynamics along a $180 \mathrm{~km}$ reach of the Saint Lawrence River from its headwaters in Lake Ontario. Hydrobiologia 2010; 647: 7-20.

Van Nieuwenhuyse EE. Response of summer chlorophyll concentration to reduced total phosphorus concentration in the Rhine River (Netherlands) and the Sacramento - San Joaquin Delta (California, USA). Canadian Journal of Fisheries and Aquatic Sciences 2007; 64: 1529-1542.

Van Nieuwenhuyse EE, Jones JR. Phosphorus-chlorophyll relationship in temperate streams and its variation with stream catchment area. Canadian Journal of Fisheries and Aquatic Sciences 1996; 53: 99-105.

Vollenweider RE. Scientific fundamentals of the eutrophication of lakes and flowing waters, with particular reference to nitrogen and phosphorus as factors in eutrophication. OECD, Paris, 1968, pp. 250.

Whalen SC, Benson PM. Influence of nutrient reduction, light and light-nutrient interactions on phytoplankton biomass, primary production and community composition in the Neuse River, USA. Fundamental and Applied Limnology 2007; 168: 257-270.

Whitehead PG, Hornberger GM. Modelling algal behaviour in the River Thames. Water Research 1984; 18: 945-953.

Yang YE, He ZL, Lin YJ, Phlips EJ, Yang JY, Chen GC, et al. Temporal and spatial variations of nutrients in the Ten Mile Creek of South Florida, USA and effects on phytoplankton biomass. Journal of Environmental Monitoring 2008; 10: 508-516. 


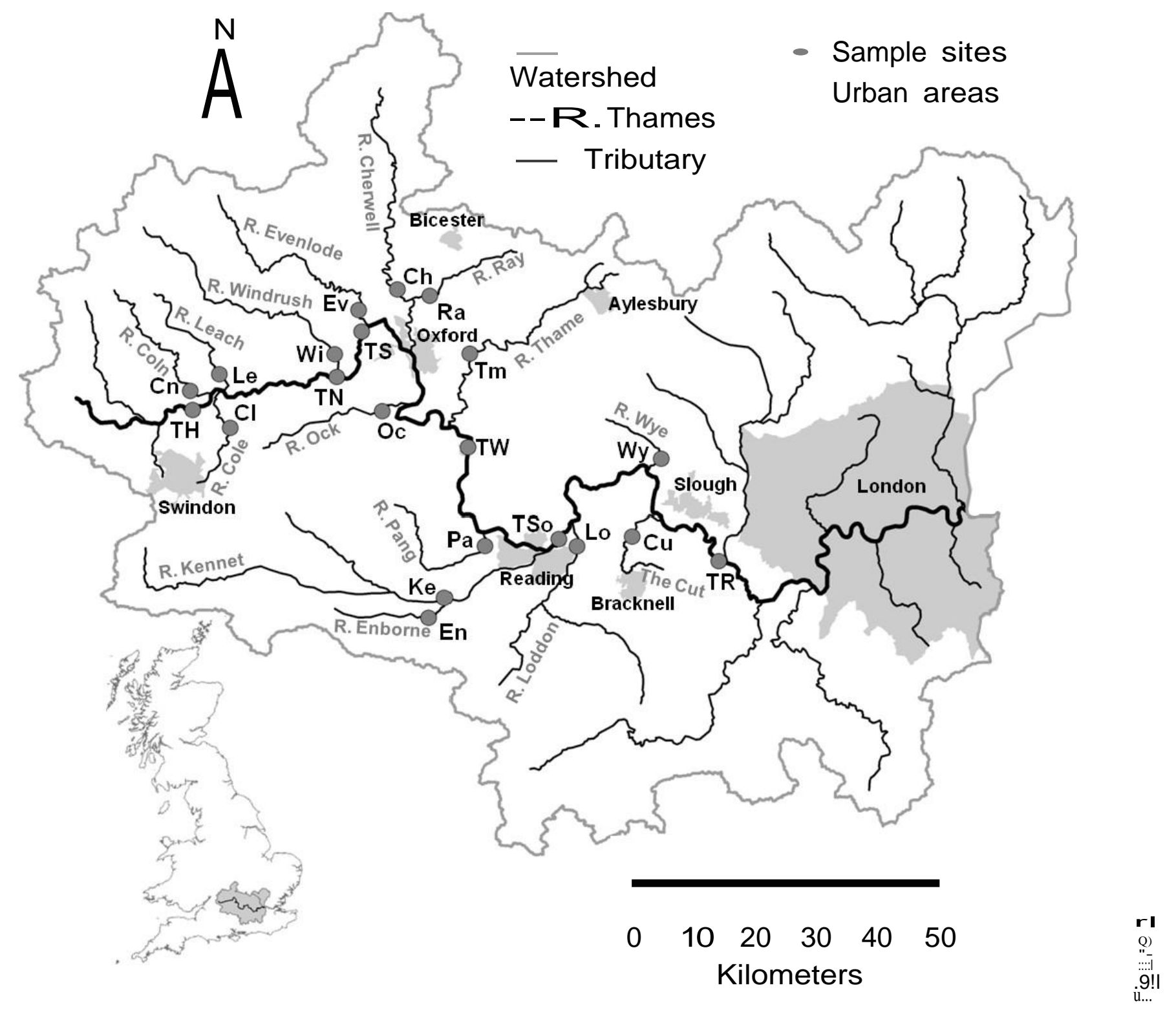


River ThameatRunnymede
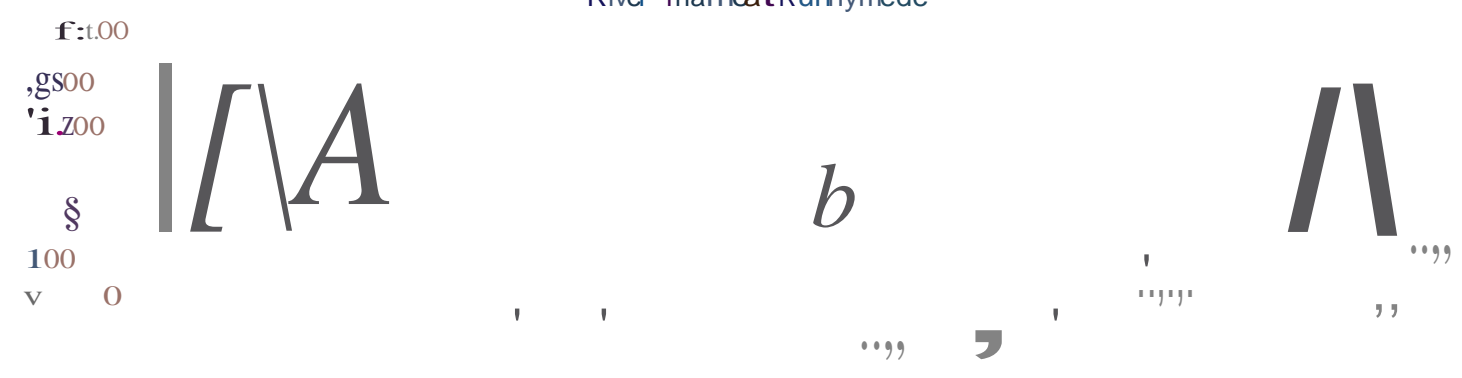

e

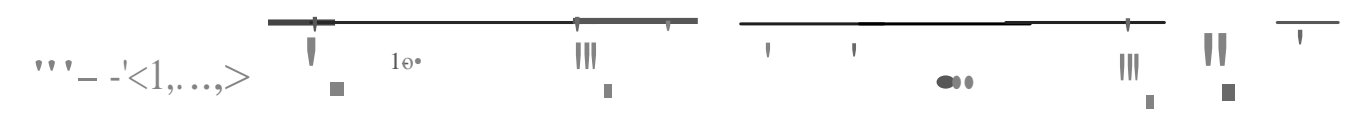

River Thameat Wallingford

I

$\therefore--=$
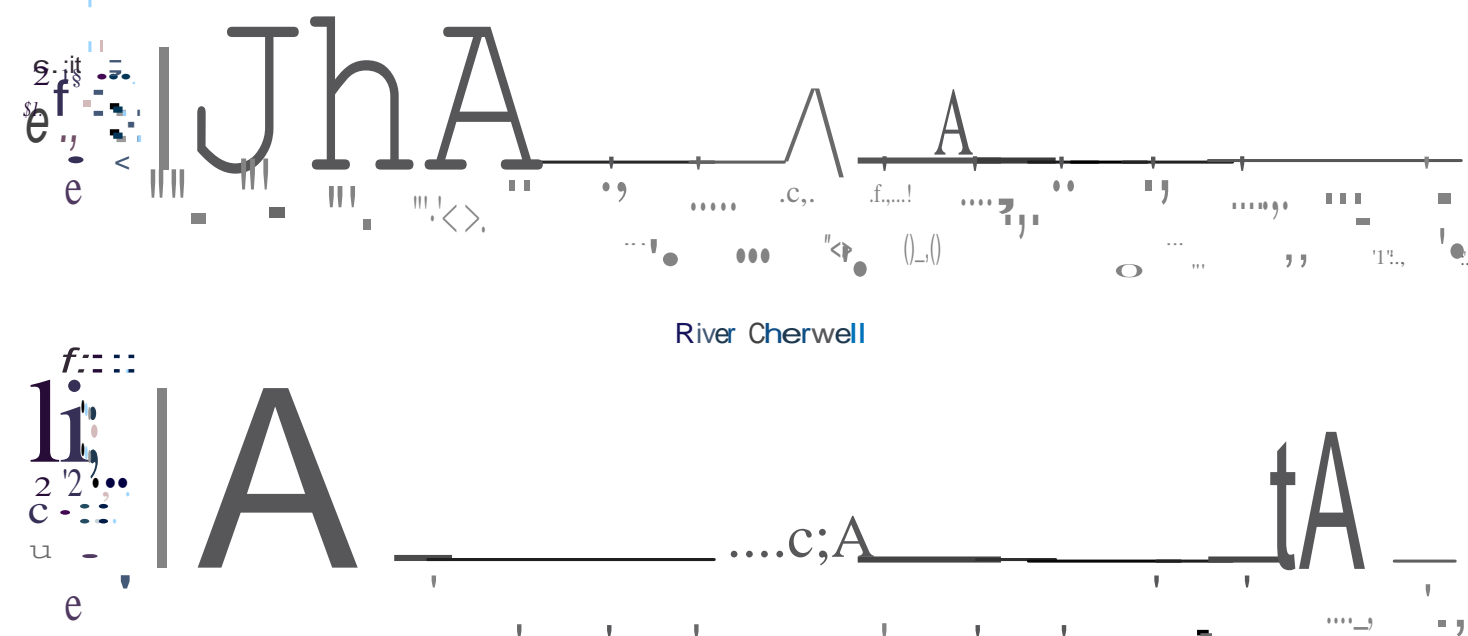

River Cherwell

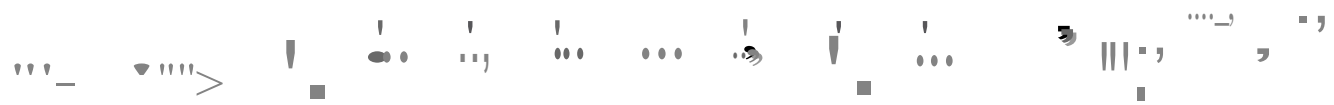

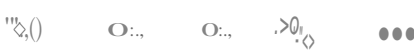
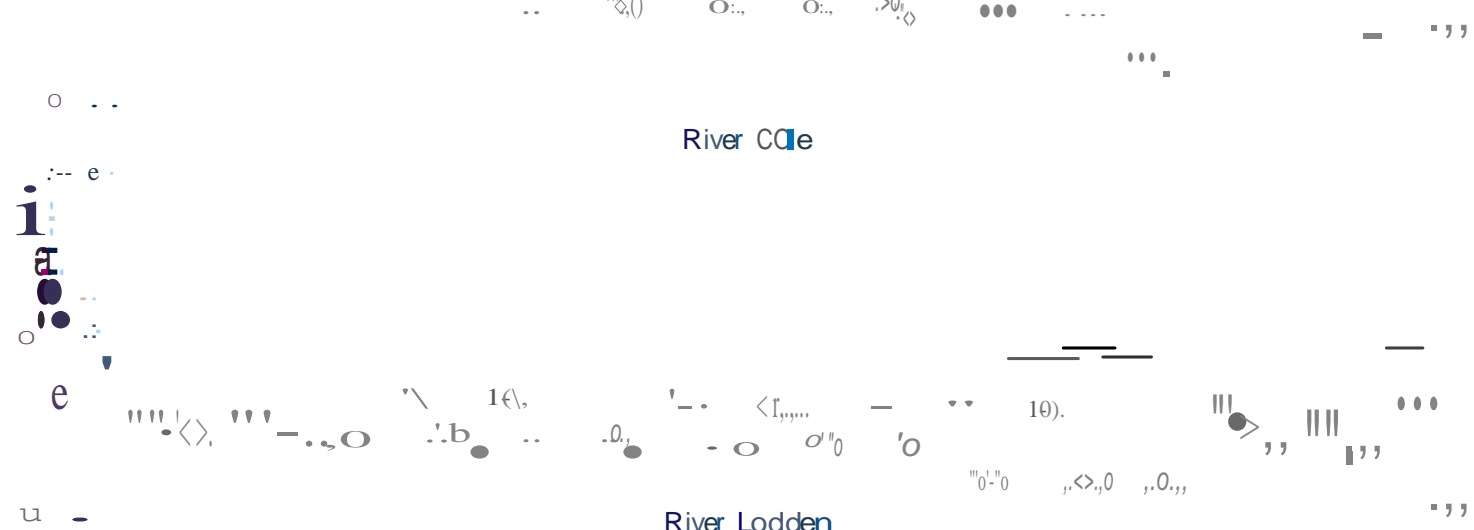

River Lodden

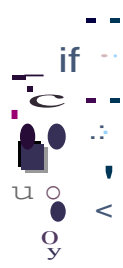

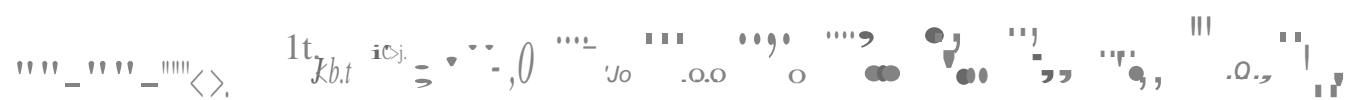


Figure 2 


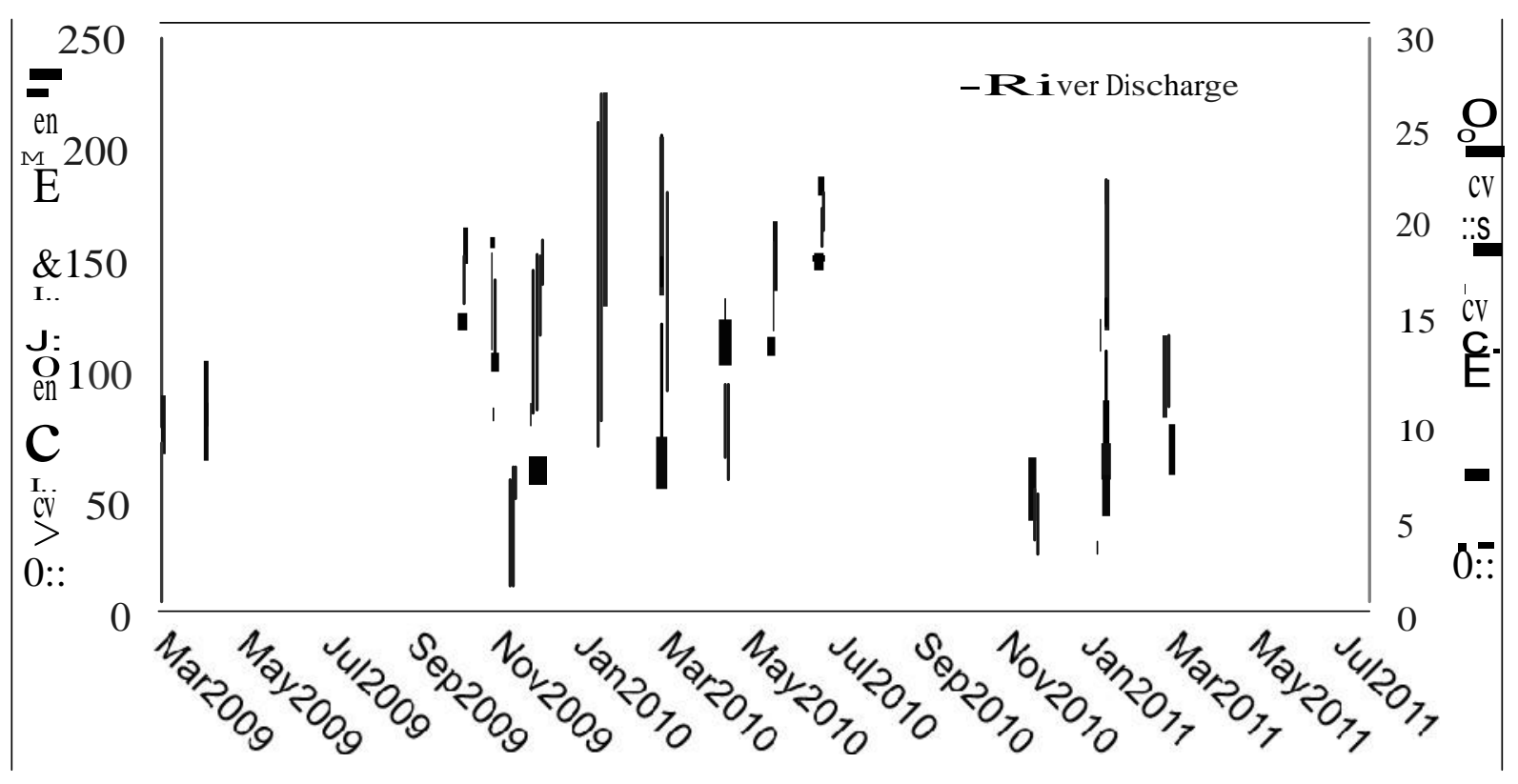

Figure 3 

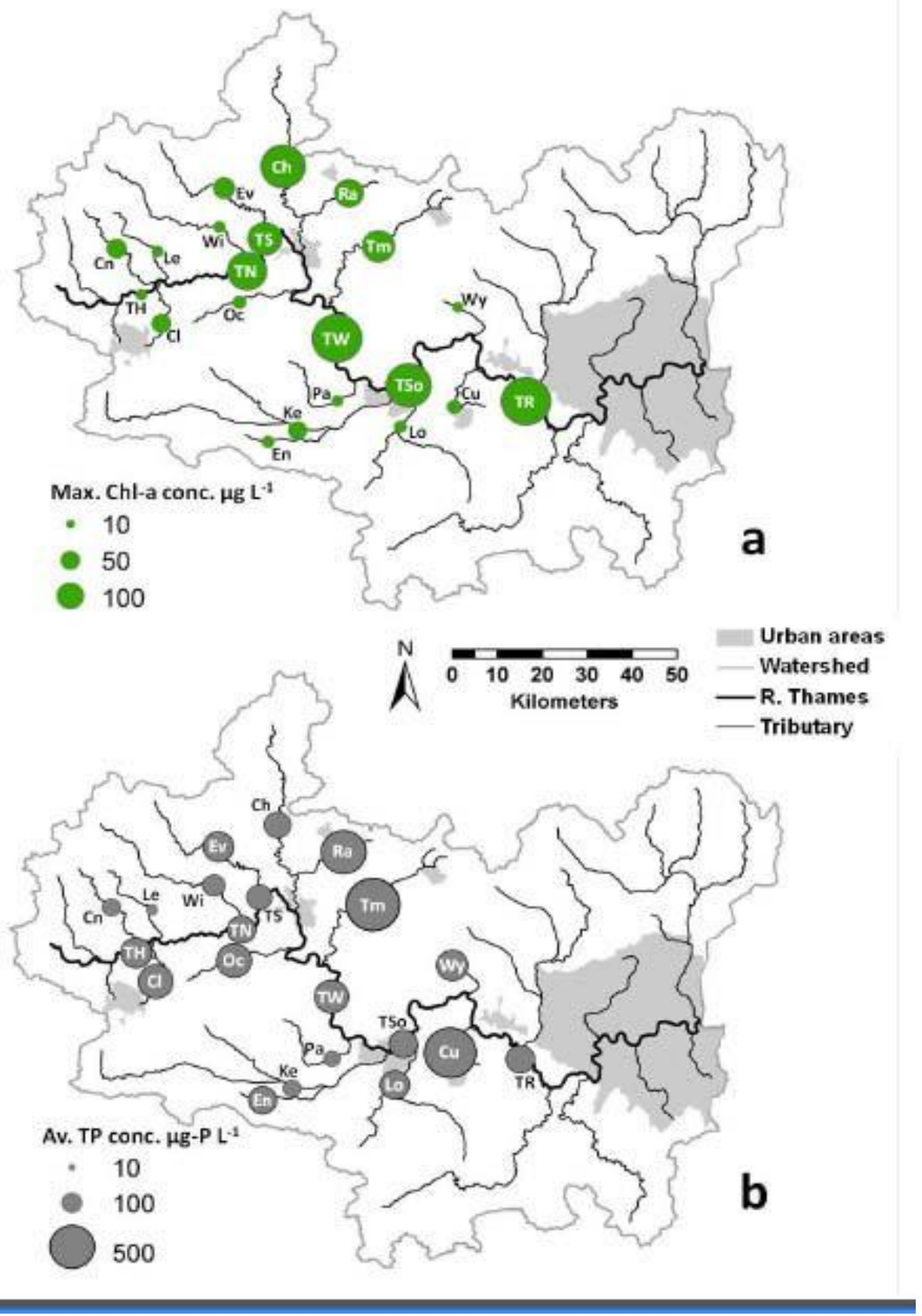

Figure 4 


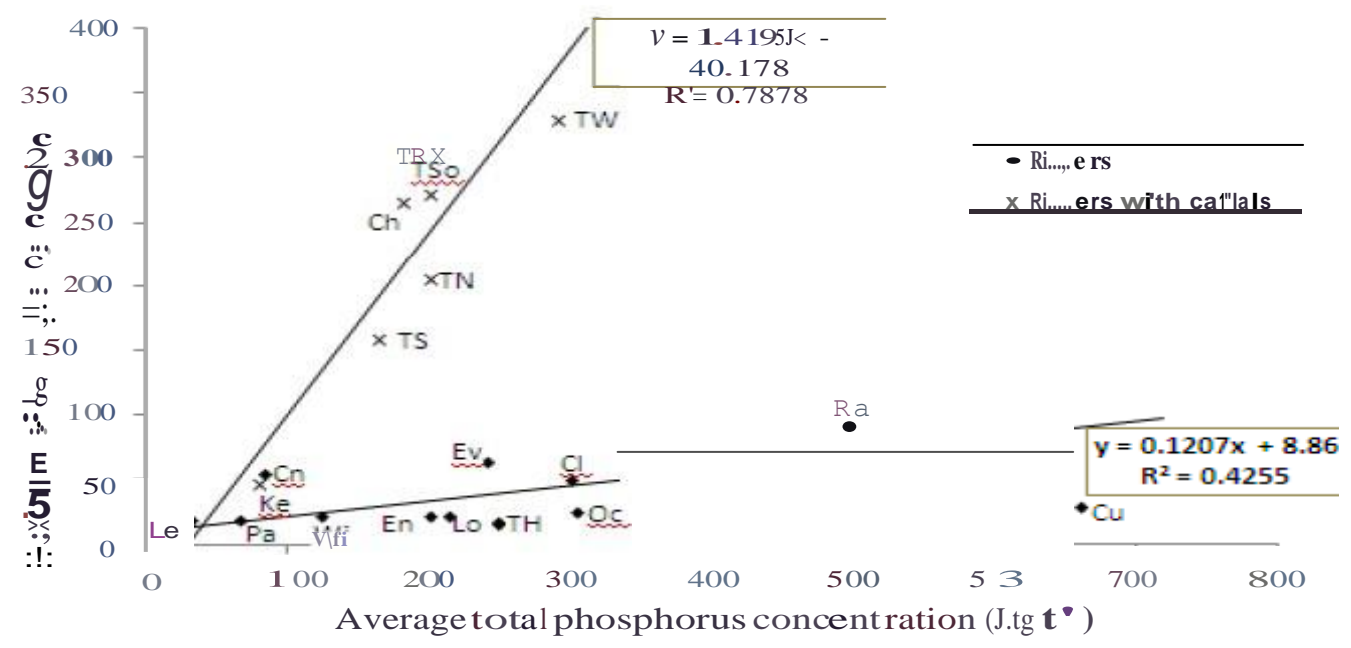

Figure 5 


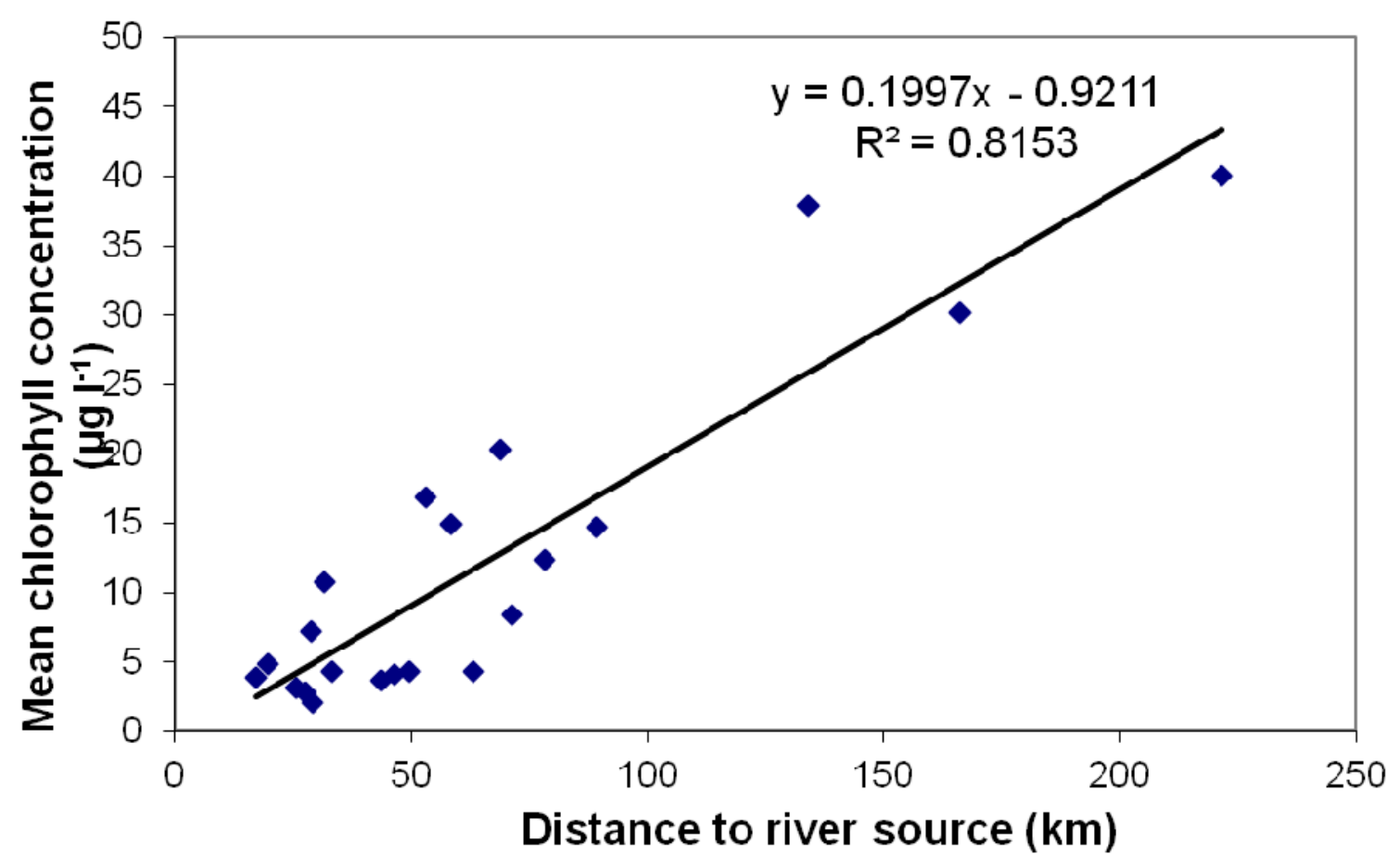

Figure 6 


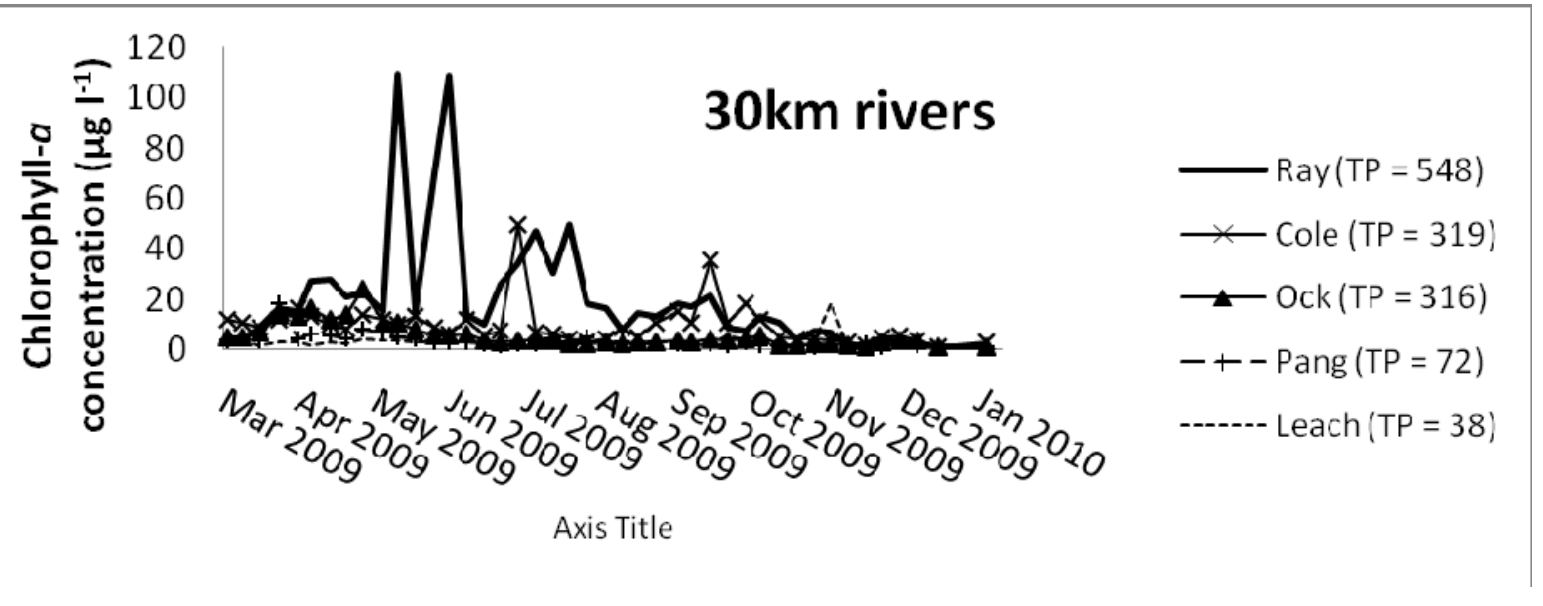

Figure 7 

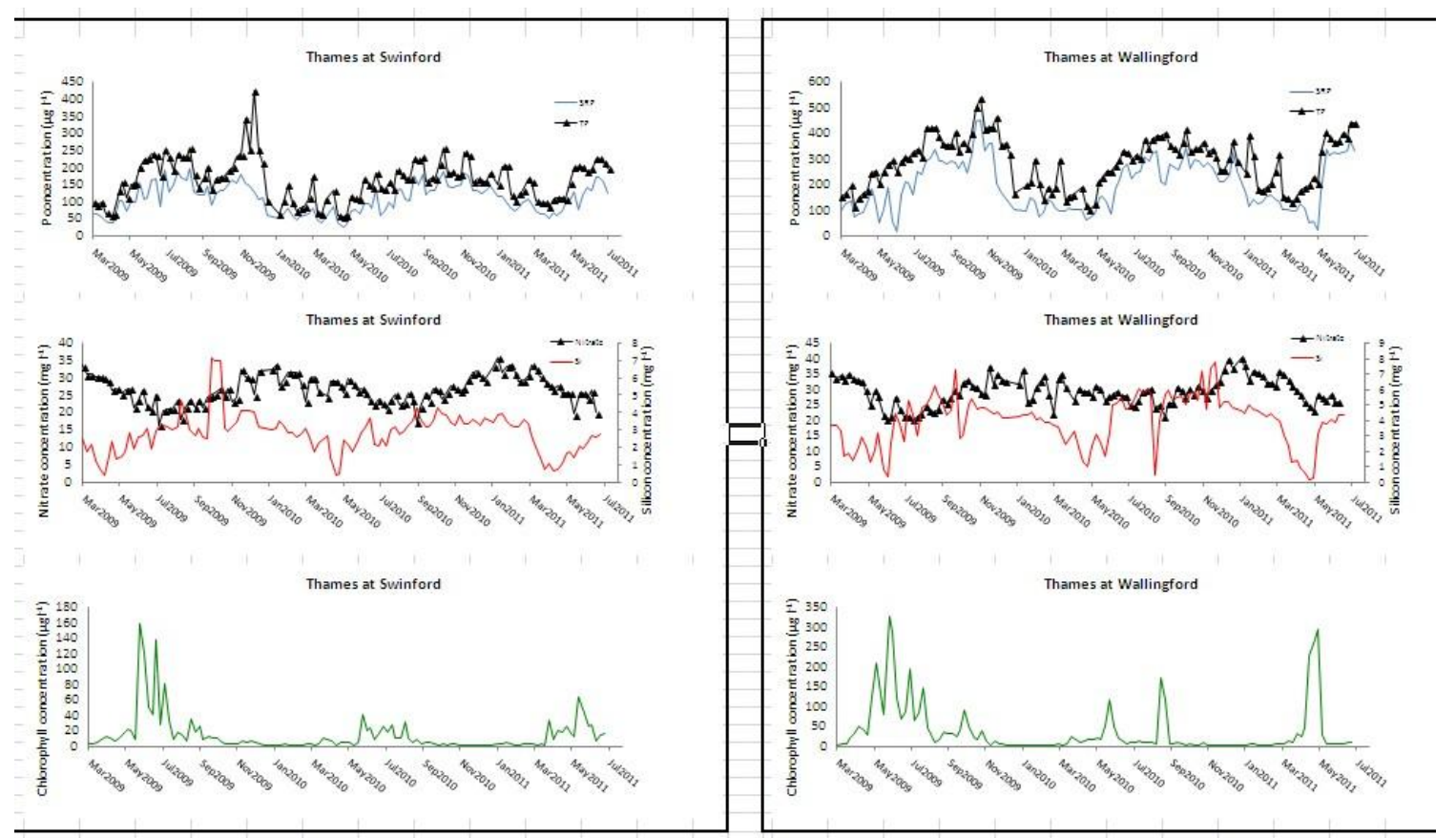

Figure 8a 

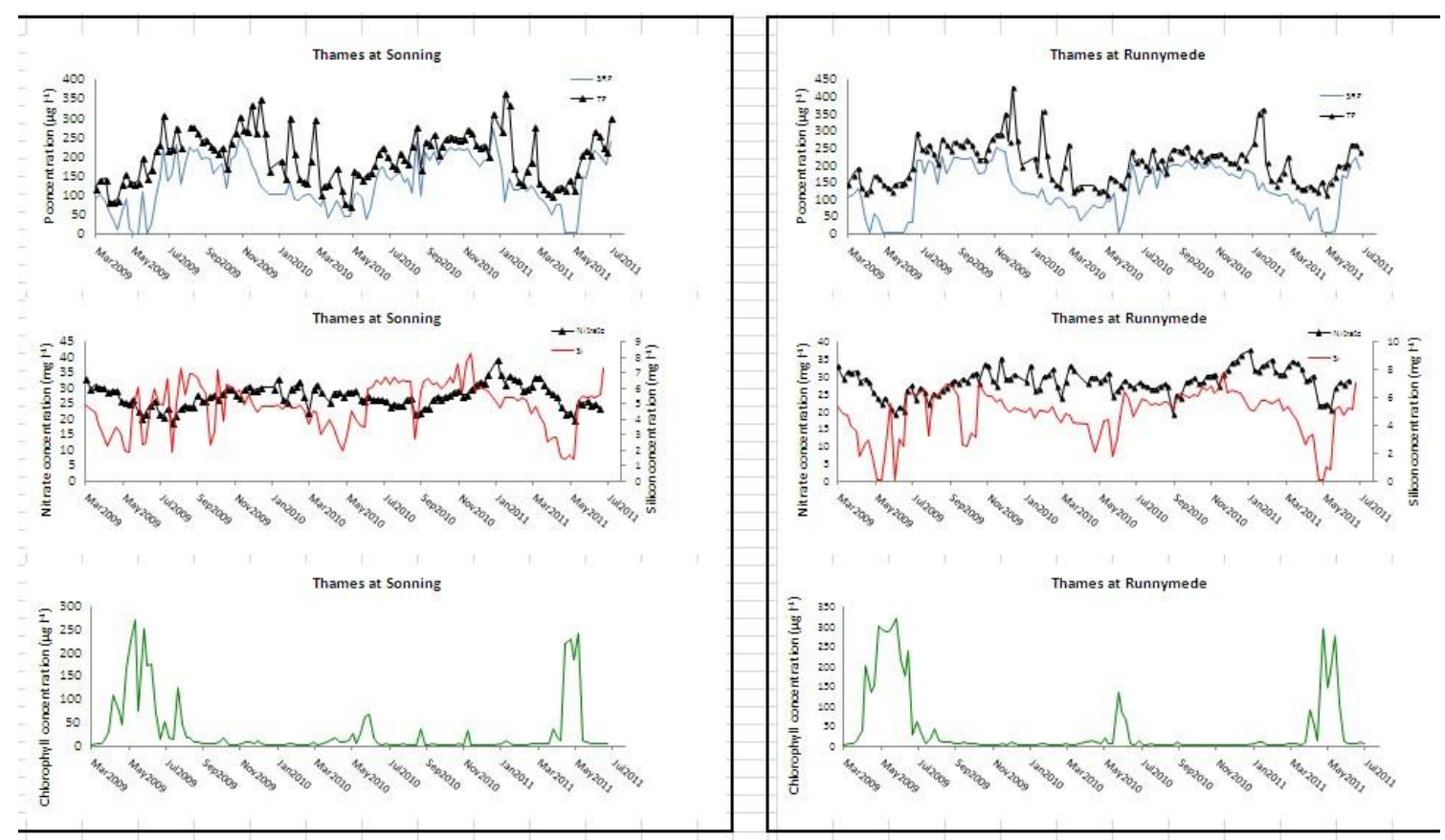

Figure $8 b$ 


\section{Table 1}

\begin{tabular}{|c|c|c|c|c|c|c|c|c|c|c|c|c|}
\hline \multirow{3}{*}{$\begin{array}{l}\text { Site } \\
\text { code }\end{array}$} & \multirow[t]{3}{*}{ River } & \multirow[t]{3}{*}{ Sampli ng site } & \multirow[t]{3}{*}{ Samplingperiod } & \multicolumn{3}{|c|}{ Chloroph yll-a (JJ,g rt } & \multirow{3}{*}{$\begin{array}{c}\text { Soluble reactive } \\
\text { phosphorus } \\
\text { t...: } r^{*} t \\
\text { Mean }\end{array}$} & \multirow{3}{*}{$\begin{array}{l}\text { Total } \\
\text { phosphorus } \\
\text { t..:r't } \\
\text { Mean }\end{array}$} & \multirow{3}{*}{$\begin{array}{l}\text { Oiss.olved reactive } \\
\text { silicon } \\
\text { t..:r"t } \\
\text { Mean }\end{array}$} & \multirow{3}{*}{$\begin{array}{r}\text { Nitrate } \\
\text { (mgrt } \\
\text { Mear }\end{array}$} & \multirow{3}{*}{$\begin{array}{c}\text { River discharge } \\
\qquad \text { (ms: } t \\
\text { Mean }\end{array}$} & \multirow{3}{*}{$\begin{array}{c}\text { Distance to } \\
(\mathrm{km} 1\end{array}$} \\
\hline & & & & \multicolumn{3}{|c|}{ Maxi mum } & & & & & & \\
\hline & & & & 2009 & 2010 & 2011 & & & & & & \\
\hline TH & Thames & Hannington lolick. & Sept 2009• July2011 & & 12 & 17 & 175 & 245 & 3.4 & 30.7 & 4.0 & 46.5 \\
\hline $\mathrm{TN}$ & Thames & Newbridge & Feb 2009 • July 2011 & 198 & 77 & 204 & 144 & 199 & 3.2 & 26.6 & 8.3 & 78.4 \\
\hline TS & Thames & Swinford & Feb 2009 • July 2011 & 158 & 40 & 65 & 109 & 163 & 2.8 & 26.2 & 11.2 & 89.2 \\
\hline$T \backslash J$ & Thames & Wallingford & Feb 2009 • July 2011 & 328 & 171 & 295 & 201 & 290 & 3.9 & 28.5 & 30.2 & 134.0 \\
\hline TSo & Thames & Sonning & Feb 2009 • July 2011 & 271 & 69 & 244 & 136 & 200 & 4.8 & 27.1 & 36.6 & 166.1 \\
\hline TR & Thames & Runngmede & Feb 2009 • July 2011 & 322 & 135 & 295 & 132 & 206 & 4.7 & 27.5 & 46.8 & 221.7 \\
\hline $\mathrm{Cn}$ & Coin & lo/helford & Feb 2009 • July 2011 & 8.6 & 53 & 42 & 59 & 84 & 2.6 & 26.5 & 2.1 & 43.6 \\
\hline $\mathrm{C} 1$ & Cole & lyntBridge & Feb 2009 • July 2011 & 49 & 9.3 & 43 & 224 & 298 & 6.2 & 19.5 & 0.9 & 28.9 \\
\hline Le & leach & lechlade Mill & Feb 2009 • July 2011 & 48 & 3.6 & 4.7 & 17 & 31 & 2.4 & 32.4 & 0.6 & 29.0 \\
\hline $\mathrm{Ji}$ & lo/indrush & Newbridge & Feb 2009 • July 2011 & 18 & 9.6 & 20 & 79 & 124 & 2.3 & 29.8 & 3.0 & 63.0 \\
\hline EY & Evenlode & CassingtonMill & Feb 2009 • July 2011 & 63 & 42 & 41 & 162 & 239 & 2.6 & 25.7 & 3.3 & 58.4 \\
\hline $\mathrm{Ch}$ & Cherwell & HamptonPoyle & Feb 2009 • July 2011 & 265 & 64 & 203 & 110 & 181 & 3.1 & 26.4 & 4.4 & 68.9 \\
\hline $\mathrm{Ra}$ & Ray & Islip & Feb 2009 • July 2011 & 110 & 44 & 24 & 405 & 487 & & 34.4 & 1.7 & 31.7 \\
\hline $\mathrm{Tm}$ & Thame & Wheatley & Feb 2009 • July 2011 & 142 & 58 & 47 & 590 & 720 & 6.3 & 37.0 & 3.1 & 53.2 \\
\hline $\mathrm{De}$ & Ock & Abingdon & Feb 2009 • July 2011 & 24 & & 21 & 246 & 303 & 6.8 & 31.7 & 1.3 & 33.3 \\
\hline $\mathrm{Pa}$ & Pang & Tidmarsh & Feb 2009 • July 2011 & 18 & 4.3 & 7.3 & 35 & 66 & 6.8 & 28.8 & 0.6 & 27.6 \\
\hline $\mathrm{Ke}$ & Kennet & lo/oolhampton & Nov $2009 \cdot$ July 2011 & & 45 & 23 & 29 & 77 & 6.5 & 23.5 & 7.3 & 71.3 \\
\hline En & Enborne & Brimpton & Nov $2009 \cdot$ July 2011 & & 21 & 12 & 129 & 201 & 6.6 & 17.1 & 1.2 & 25.5 \\
\hline Lo & lodden & Charvii & Feb 2009 • July 2011 & 21 & 15 & 15 & 130 & 213 & 5.2 & 33.9 & & 49.6 \\
\hline $\mathrm{Cu}$ & TheCut & Paley Street & Feb 2009 • July 2011 & 19 & 13 & 28 & 491 & 662 & 5.9 & 86.4 & & 19.5 \\
\hline Wy & IJye & Bourne End & Feb 2009 • July 2011 & & 10 & 15 & 184 & 246 & 6.4 & 27.1 & 1.0 & 17.3 \\
\hline
\end{tabular}


